\title{
THE ELECTION CONFLICT OF MANDAILING TRIBE LEADER: AN ANALYSIS ON VICTIMOLOGY
}

\author{
By \\ Kasmanto Rinaldi \\ Department of Criminology, Universitas Islam Riau, Indonesia \\ Email: kasmanto_kriminologriau@soc.uir.ac.id
}

\begin{tabular}{l}
\hline \hline Article Info \\
\hline Article history: \\
Received Nov 11, 2021 \\
Revised Dec 21, 2021 \\
Accepted Jan 20, 2022
\end{tabular}

Keywords:

Conflict,

Community,

Victimology

\begin{abstract}
In the study of victimology, it was explained that some of community members tended to be repeatedly victims of crime. So, as long as there is no recovery carried out regarding this problem, the community is described as continuing victimization. This happened in Sei Kumango Village, Sub-distric Tambusai, Rokan Hulu Regency, Riau Province. There is a confilct about the election of the Mandailing tribe leader in that village, and it made the community be in a very disadvantaged situation. Through qualitatives research approach, this research explained the conflict that occurs causes an adverse impact on the community in a psychological aspect and cultural aspect that exist in the community itself. In victimology, that problem is described as a form of Politically Victims, that is those who suffer because of their politic oponnent where it was explained that the conflict's impact which had afflicted the community in both camps was an impact that occurred because of the leader election. Indirectly, the community became political victims of leader's election in Mandailing tribe, Sei Kumangi village.
\end{abstract}

This is an open access article under the CC BY-SA license.

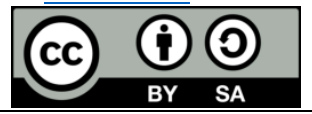

\author{
Corresponding Author: \\ Dr. Kasmanto Rinaldi, \\ Department of Criminology, \\ Universitas Islam Riau \\ Jl. Kaharuddin Nasution No. 113, Pekanbaru, Province of Riau, Indonesia \\ Email: kasmanto kriminologriau@soc.uir.ac.id
}

\section{INTRODUCTION}

The discussions about victimology and the part of criminologi began since Von Hertig (1941) who published an article with the tittle "Remarks on The Interaction of Perpetrator and Victim". Those article has triggered a deeper discussion about how the role of victims can cause the crimes. In an early explanation about victimology have been introduced the terms about victims, such as victimization experinces, that is the experince being a victim of crime, and victimization is factors that influence the emergence of victimizaton experinces. [1]

From several existing studies, it was explained that from community members there were some members of the community who tended to be repeatedly victims of crime. The repetition of being a crime's victim is called as multiple victimization. However [2] there are also people who experince victimization continuously, such as the community groups who being victim of enviromental pollution that dont see any steps to restore enviromental conditions. This situation called as continuing victimization.

The social problem is the behavorial patterns or the situastion that are demmed blamed or disliked by some of community members. The community members argued that improvement policies, plans and services were necessery for successful methods, reducing the extend of those problems. [3] The things above like what happened in a community groups in Sei Kumango Village, sub- distric Tambusai, Rokan Hulu regency, Riau Province. The existance of the conlict in Mandailing leader's election in Sei Kumango village made various impacts that adversly affect the overall community living in that village. The conflict is known to have lasted three years, it made the situations less condusive for the people in Sei Kumango village and it divide community groups. 
The conflict that occured fatalities and the death of a public figure in that village. As reported by riauoke.com the public figure in Tambusai village died because murdered by his neighbor. Even though the news explained how the chronology of that murder occured, it caused by the land conflict. But, from the pre-survey the researchers did, according to the Sei Kumango villagers, there was a connection between murder cases that occured with the problem of the Mandailing tribe leader's election in that village.

Not only the murder case, the impact of social conflict arising from the problem of the Mandailing tribe leader's election in Sei Kumango Village also made the people anxious because that creations of divisions and supporting blocks for each community in that region. This condition creates social conflicts that have an impact to the discomfty communitysituation in Sei Kumango village, sub-distric Tambusai, Rokan Hulu regency.

The study about victims as it was described above in criminology it has become an interesting part of the analysis to discuss. As part of criminology object, the study about victims is discussed spesiffically in the victimology studies. Victims are always identified with those who have criminal insidents experimces. But there are still many victims which explicitly that victims must not directly experince criminal incidents. On other hand, Becker [4] explained that giving negative social reactions can lead to deviant behavior, especially for young people.

Conflict according to McCullum (2009) is something natural that happens in human life. The occurance of conflict is a necessity in the process of interaction between individuals, individuals with groups, groups with groups, each of groups causes the differences in the background of interaction, ability to interact, and the purpose of interacting. [5] Conflict also occurs in Indonesia people who have different political, ethnic, tribe and different religions. Kibriz (2014) explained that there is a conncetion between the social conflicts that occur in thecommunity with the high education in that area. Education gets distrubances due social conflict that damage the welfere of community if it left alone. [6]

The election of leader as a venue for political consolidation at the certaint tribal level should provide political education that educates the community. Because that tribal community is openly faced with its prospective leaders. The election of the leader certainly identical to politic campaigns, because the prospective leader who will be elected are who can support development for the tribe itsels. The interesting thing to study in the implementation of the election of the tribe leader is the stage of the campaign where each prospective leaders competes to introduce himself, giving promises, approach the village community, and severalother approaches through the communication, directly by the prospective leaders or by their team.

\section{RESEARCH METHOD}

The method that used in this research is qualitative method with descriptive approach. Qualitative research can be defined as a social science research who tried to collect and analyze the data in those kinds of words or written as the actions of humans and researchers to calculate the qualitative data that has been obtained. Data that has been analyzed by researchers in qualitative research is can be seen in the form of words and actions that committed by humans [7]. Bungin in quotes all qualitative research in several ways reflect perspective phenomenological. That is, researchers trying to understand the meaning of a events and interactions for ordinary people in certain situations. [8]

A study requires a variety of techniques to collect and learn more about the phenomena that occur in society. Therefore, there are 3 techniques that used to collect the data of the research.

1. Observation

The first thing to do in data collection techniques is observation. Observation is an observation activity and systematic recording with symptoms that often occur depending on the target location and what you want to research directly.

2. Interview

Interview is an activity by means of interpersonal communication in accordance with the objectives to be achieved. There should be two things in the interview. First, there must be an interview seeking informants, and secondly, there must be suitable informants for the interview.

3. Documentation

These activities are carried out by extracting information certain of the documents related to the problem at hand investigated. The data obtained from the documentation technique.

Data is all information that is used and processed for an activity research so that it can be used as a basis for decision making.[9] According to Kuncoro, data is a collection of information needed for decision making decision. The types and sources of data used in this study are:

1. Primary Data

Primary data is the collection of research data based on the results of interviews with key informants. 
International Journal of Social Science (IJSS)

Vol.1 Issue.5 February 2022, pp: 675-680

ISSN: 2798-3463 (Printed) | 2798-4079 (Online)

DOI: https://doi.org/10.53625/ijss.v1i5.1310

\section{Secondary Data}

Secondary data is data that comes from laws, documents or records, books and documents or archives and other confidential information related to research [10]

\section{RESULTS AND ANALYSIS}

The Mandailing tribe conflict that occured in Sei Kumango village is the conflict that occuredbecause of the leader's election which is not yet agreed by all the community in those village. The community seperated into two camps because there are two candidates based on lineage were deemed fit to be indigenous leaders of the Mandailing tribe, better known as thecustomary king. The previous custumary king (alm. Mr. Panusunan Hasibuan) before he passed away and relinquished his position as a leader hadn't assign to whom the nextcustomery king afterwards. This polimic felt so big when the supporting community from the both camps of community felt the candidate they had is the best person to replace Panisunan costumery king. As a result, the people who divided were in conflict and made the situation in Sei Kumango village become not harmonious. Until it causes thing that are detrimental from both sides. These impacts appear in a quite diverse form in the community.

\section{1 The importance of Victimology analysis}

In more than two centuries, the victims' interests of crime were ignored by the law. This happened because the problem of crime according to the law is a public problem or a state problem. Violating criminal law is considered as violating the interest of the state. The victim of crime is not considered as an important thing. As long as the criminals are punised,for the law that problem is over. In reality, the interests of victims are totally ignored. In fact, sometimes the victims of crime are blamed for the fate that happened to them, as their own fault. The discussions will always be interesting if it discusses about the forms of crime or the criminals, but the victims' analysis seems to be ignored or just put as number two. Asexplained by Henry and Milovanovich (2000) deny the ideas that crime and the criminals (perpetrator of crime) can be seperated from social process in society, seperate from the whole social process. It means the crime is the result of joint production through discourse in the interrelation of humans with cultural products, community social institutions and broad social structures. [11]

Victimology has not succeeded in defining itself around its object of study since it recognized as a field devoted to the study of victims and victimizations, even today the proid of a number of theoretical gives rise to remarkable semantic confusion. It was very tricky to find a sufficiently solid methodological line to make it possible to list, or even identify, the 'victimological' articles of the journal over a period of 50 years. it is therefore the simplest method which has been adopted: after having counted the total entries in all the numbers published (number of titles, including articles, excluding themes, editorials, etc.), the entries evoking directly the theme of victimization or victims (a search by keywords was simply carried out).[12]

Studying victims of crime is part of criminology that can't be seperated. An understanding about experience of being a crime's victim or criminals' victimization makes criminology more objective in studying crime. In addition, victimization also triggers concrete steps in protecting the interests of victims, in the form of compensation for victims and advocacy and assistance for victims who experience traumatic impacts on their victimization experiences. Then referring to the overall data and analysis available, the community in Sei Kumango village if connected to the victims typology as presented by Schaffer, it classified as Politically Victims, that is they are who suffering because of their political opponents. It was explained that conflict impact had afflied the community in both camps is the impact that occured because of the leader's election. Indirectly, the community became victims of leader's election in Mandailing tribe, Sei Kumango village. [13]

\subsection{Physicological Impact of the Community Conflict In Sei Kumango Village}

As how it explained by Maslow (1943) the conflict that occurs can cause trauma, always feel insecure even reduce / loss self confidence from individuals in that community. This thing is really felt by the both camps that were in conflict in Sei Kumango village because of that costumary king election. Every individual have different needs which is different with other, and those needs must be fulfilled according to their respective levels. Maslow further explained that the individual needs level is related to the life needs to achieve the calmness that must fulfilled in every individuals is a physiologycal needs, safety needs, social and belongingness need, self esteem needs, self actualization needs. The existance of the conflict is a shock for the people who were in conflict as well as the other people who get the impact of the conflict. This thing made trauma, always feel insecure, even reduce/loss self confidence, and it will be hard to restored back to normal. [14]

From several criteria problem for the psychological impact of conflict, impact of conflict is related with the safety need, and self esteem needs are top two indicators collide or fight against each other that occur in the Sei Kumango village. Where the community really needs the safety feeling that is need to be in community. However, as the community who support their champion camps and believe that their camp is the best person who 
will be the next costumery king. So the self esteem need became the opposite indicator untill the feel or the desire for peace in Sei Kumango village can't be run properly. The existence of self esteem need that the cummunity have from each camps made the safety need became something that can't be done well or distrubed. 3.3 Cultural Impact Of The Conflict That Occured In Sei Kumango

From the explanation that presented by Maslow illustrates that the collapse of cultural valuesand the loss of authority of a culture are the effect of conflic between citizens. This thing can cause no longer a sense of pride, confidence in citizens who have a culture. As a result modernization will eliminate a culture that exists. The condition of modern humans will change the prespective of an individual, when individual no longer valued in the side of age. Modern humans see and value individual in the side of their expertised and skills. It different with the traditional community who seeindividual from the side of age, senority, and juniority.

In any complex and pluralistic society peace cannot be equipped with absence of any comunity. on the contrary, since conflict are a normal element of life in a community, a peaceful society exist where, together with The collective renouns to align violence as a way of solving conflict, the respect of fundamental rights is normally guaranteed and approach create and everything effort are developed in order to prevent and give the necessary answer to their violation. Owing to the essential nature of justice and freedom, the Reconstruction of the social tissue affected by violence urges the adoption of important effort of extension and reinforcement of the democratic culture and particularly the promotion of the culture of human Rights and human dignity as the basic ethical social of any baseball associated this is a task that require the collective action of all political agent and social and public institutions and active participation of victim is also desirable in order to elevate it their suffering and avoid the risk of exclusion. [15]

So, analyzing the above statement with the data in the field is prove that the conflict that occured Sei Kumango village caused offense to the culture. For example, described by a community member in Sei Kumango village, if there is costum of marriage, then each camp will invlove a costumery king who is right according to them. So, it no longer involves all community in Sei Kumango village. Added, when there are major religious and cultural days, then it is not common for this to be overlooked because of the tension of the conflict that is still ongoing in the region. The costum of marriage became a cultural impact that really felt in Sei Kumango village in Mandailing tribe who get the impect of the election leader conflict. The people who had been entereched before were confused when they want to marry traditionally, which costumary king that they must tell and which costumery king they must invite. Carrying out customary marriages before there is a conflict that unites the whole community no longer seems to be shared because of the conflict.

\section{CONCLUSION}

The conflict that occured in Sei Kumango village due to the election of Mandailing tribe leader in that village. The community seperated into two camps because there were two candidates based on lineage considered appropriate to be traditional leaders the Mandailing tribe or better known as the customary king of the Mandailing tribe. So, from the result of reseach and discussion, the researcher concluded that the conflict in the election of the Mandailing tribe costumery king in of Sei Kumango village has a conflict impact which is divided into four explanations, there are the impact of psychological, economic impacts, social impacts and cultural impacts.

The impact of psychological is emphasis on two conflicting indicators between the need for self-esteem need to be high because it feels that the candidate from his family is appropriate, resulting in a security need indicator that is difficult to manifest. As well as the social impacts that occur cause emotions and stress in society, limited communication to the emergence groups of groups that are divided. Whereas the cultural impact was also felt by the people of Sei Kumango village in the Mandailing tribe because of this dualism, where traditional events such as marriage became disturbed and did not work as they had previously done because of community confusion over the conflicts that occurred.

\section{REFERENCES}

[1] H. H. Von, "Remarks on The Interaction of Perpetrator and Victim," J. Crim. Law Criminol., 1941.

[2] Muhammad Mustofa, Kriminologi Kajian Sosiologi Terhadap Kriminalitas Perilaku Menyimpang dan Pelanggaran Hukum Edisi Kedua. Bekasi: Sari Ulung Pratama, 2010.

[3] R. . Fuller and R. F. Myers, "Some Aspects of A Theory of Social Problems," Am. Sociol. Rev., 1941.

[4] H. Becker, Outsiders. New York: Free Press, 1963.

[5] S. McCollum, Conflict Education; Managing Conflict Resolution. New York: Chelsea House, 2009.

[6] A. Kibris, "The Conflict Trap Revisited: Civil Conflict and Educational Achievement.," Sage Journals, 2014.

[7] Afrizal, Metode Penelitian Kualitatif. Jakarta: Raja Grafindo Permai, 2014. 
International Journal of Social Science (IJSS)

Vol.1 Issue.5 February 2022, pp: 675-680

ISSN: 2798-3463 (Printed) | 2798-4079 (Online)

DOI: https://doi.org/10.53625/ijjss.v1i5.1310

[8] A. Mayasari and K. Rinaldi, "Dating Violance Pada Perempuan (Studi Pada Empat Perempuan Korban Kekerasan Dalam Hubungan Pacaran Di Universitas X)," Sisi Lain Realita, vol. 2, no. 2, pp. 76-89, 2017, doi: 10.25299/sisilainrealita.2017.vol2(2).2466.

[9] H. B. Bungin, Metode Penelitian Kualitatif. Jakarta: Pranamedia, 2015.

[10] Suryana, Metodologi Penelitian. Bandung: PI, 2010.

[11] D. Henry, S. \& Milovanovic, Constitutive Criminology: Origins, Core, Concepts, and Evaluation. New York: State University of New York Press, 2000.

[12] C. Rossi and A. Gaudreault, "Cinquante ans de victimologie: Quelle place pour les victimes d'actes criminels dans la revue Criminologie de 1968 à aujourd'hui?," Criminologie, vol. 51, no. 1, pp. 271-290, 2018

[13] I. Maya, Perlindungan Korban: Suatu Prespektif Viktimologi dan Kriminologi. Jakarta: Kencana, 2014.

[14] A. . Maslow, Conflict, Frustation, and Theory of Threat. J. Abnorm: Psychol, 1943.

[15] J. L. de la Cuesta, "Victimological Challenges and Restorative Justice in Present Basque Country," Neue Kriminalpolitik, vol. 27, no. 2, pp. 148-157, 2015 
